\title{
MOTIF PERILAKU BIBLIOCRIME DI UPT PERPUSTAKAAN UIN RADEN FATAH PALEMBANG
}

\author{
Linda Maryani dan Herlina \\ Prodi Ilmu Perpustakaan Fahum UIN Raden Fatah Palembang \\ Email: linda@gmail.com
}

\begin{abstract}
Introduction. This study aimed to determine the behavioral motives of bibliocrime in Library of UPT Raden Fatah Palembang. This study aims to find out what the motives of the user do bibliocrime, how the impact and prevention efforts have been made by the library.

Data Collection Method. Methods of data collection using observation, interview and documentation techniques.

Analysis Data. (1) data collection, (2) data reduction, (3) data presentation, and (4) conclusion drawing.

Results and Discussions. The results showed that the backgrounds motive of user doing bibliocrime was based on the need to fulfill lecture assignments and final assignments, selfactualization, overflowing hatred, wanting to utilize collections exclusively for personal interests, expensive photocopying fees, difficulty finding collections, collections which cannot be loaned, collections that are in demand, collections that are stagnant, forgotten, lazy and have a certain busyness. UPT Raden Fatah Library UPT Palembang have two losses experienced are social losses and financial losses. Social losses in the form of poor library images. While financial losses, the library must replace lost and damaged collections. The three prevention efforts that have been carried out by UPT Raden Fatah Library of Palembang are installing CCTV, security gates, and user education.

Conclution. Based on the findings, the backgrounds motive of user doing bibliocrime in UPT Raden Fatah Library UPT Palembang, They have two losses experienced, and they have three efforts to prevention of bibliocrime.
\end{abstract}

Keywords: Bibliocrime, motive, Library of UIN Raden Fatah Palembang.

\section{A. PENDAhULUAN}

Setiap bagian dari perpustakaan harus dapat secara bersama-sama menjaga koleksi perpustakaan demi kepentingan bersama agar dapat digunakan oleh setiap pemustaka. Sesuai dengan pernyataan dalam Pasal 6 UU No. 43 Tahun 2007 menyebutkan "Bahwa masyarakat berkewajiban menjaga dan memelihara kelestarian koleksi perpustakaan." Namun, tidak semua pemustaka dapat menjaga koleksi perpustakaan dan mengikuti peraturan yang berlaku di perpustakaan 
tersebut. Banyaknya koleksi dan berbagai macam aturan yang ada di perpustakaan memberikan dampak ancaman terhadap perpustakaan, terutama kerusakan pada koleksi.

Dalam pemanfaatannya koleksi-koleksi perpustakaan tidak terlepas dari kehilangan maupun kerusakan. Koleksi dapat mengalami kerusakan karena faktor alam maupun manusia. Manusia yang dalam hal ini pemustaka, dapat melakukan penyalahgunaan koleksi berupa kerusakan fisik, dokumen kotor, goresan pada rekaman, merobek buku, bahkan dapat menyebabkan hilangnya koleksi dari perpustakaan. Pemustaka terkadang secara sengaja merusak koleksi demi kepentingan mereka sendiri tanpa memikirkan dampak yang akan terjadi akibat dari ulah mereka (Damayanti, 2015: 147-154)

Beberapa tindakan tersebut di atas merupakan bentuk tindakan bibliocrime. Bibliocrime dipahami sebagai bentuk penyalahgunaan terhadap koleksi yang dilakukan oleh pemustaka yang tidak bertanggung jawab dalam menggunakan koleksi. Menurut Obiagwu (1992: 291-292), tindakan bibliocrime dapat digolongkan menjadi empat, yaitu pertama pencurian (theft), kedua penyobekan (mutilation), ketiga Peminjaman tidak sah (unauthorized borrowing), dan keempat, Vandalisme (vandalism).

Perilaku bibliocrime sangat berbahaya karena akan berdampak buruk bagi perpustakaan, antara lain seperti terhalangnya transfer informasi dan ilmu pengetahuan serta kemajuannya, biaya preservasi bahan pustaka yang meningkat, mengurangi bahkan menghilangkan keindahan koleksi, berdampak sosial pada lingkungan dan diri objek misalnya menularnya kebiasaan melakukan tindakan bibliocrime kepada orang lain, dan lain sebagainya (Wahyudiati, 2018). Dengan adanya perilaku bibliocrime tersebut tentu mengakibatkan kerugian yang sangat besar bagi perpustakaan. Adapun kerugian tersebut terbagi atas dua yaitu kerugian secara sosial dan kerugian secara finansial.

Kerugian sosial adalah kerugian yang dialami oleh perpustakaan dan pemustaka. Karena adanya koleksi yang rusak antara lain adalah berkurangnya kepercayaan atau dapat memberikan suatu citra (image) yang kurang baik terhadap perpustakaan sebagai gudang informasi. Misalnya perilaku mutilasi dapat 
menimbulkan rasa marah dan frustasi pengguna yang menginginkan suatu artikel di suatu majalah yang ternyata tidak ada karena telah dirobek orang lain. Kerugian finansial adalah kerugian yang dirasakan oleh perpustakaan dalam hal dana yang harus dikeluarkan untuk mengganti koleksi yang rusak, memperbaiki kerugian kertas dan menjaga kualitas bahan pustaka (Adrimon dan Malta, 2013).

Secara umum, perilaku bibliocrime yang sering terjadi di perpustakaan, dipengaruhi oleh beberapa faktor seperti kemudahan akses, koleksi yang diminati, usia pemustaka, jam buka operasional, kurangnya pengamanan, kurangnya pelatihan staf dalam pencegahan kejahatan, fasilitas fotokopi, desain gedung dan ruang, serta peraturan perpustakaan (Listiyani, 2010: 29). Berdasarkan kenyataan di atas menunjukkan bahwa pemustaka sangat dipengaruhi oleh berbagai hal yang bisa memberikan peluang bagi mereka untuk melakukan bibliocrime baik itu faktor dorongan dari diri individu itu sendiri maupun dari faktor luar.

UPT Perpustakaan UIN Raden Fatah Palembang, sebagai perpustakaan perguruan tinggi yang menerapkan layanan Open Access dan kemudahan akses informasi, menyebabkan rentannya terjadi perilaku bibliocrime. Dikarenakan pada layanan Open Access, pemustaka dapat secara langsung datang ke rak mencari koleksi yang diinginkannya. Peluang untuk melakukan bibliocrime pun menjadi lebih besar.

Di samping itu, berdasarkan pengamatan yang dilakukan oleh peneliti telah ditemukan koleksi yang robek. Beberapa pemustaka juga mengaku pernah menggunakan kartu pengguna perpustakaan milik orang lain untuk meminjam buku dengan alasan kartu pengguna mereka tertinggal maupun hilang. Selain itu ada juga yang mencoret-coret buku dengan alasan untuk menandai bagian-bagian buku yang dianggap penting. Beberapa hal tersebut menunjukkan bahwa bibliocrime sudah pernah terjadi di perpustakaan UIN Raden Fatah Palembang.

Untuk dapat mencegah perilaku bibliocrime ini, perlu diketahui dan dipahami motif apa yang melatarbelakangi pemustaka dalam melakukan tindakan bibliocrime tersebut. Dengan mengetahui motif-motif perilaku bibliocrime, pihak perpustakaan dapat memahami apa yang menjadi keinginan pemustaka dan dapat mencari jalan keluarnya agar perilaku bibliocrime tidak terus menerus terjadi di 
perpustakaan. Untuk itulah, peneliti tertarik untuk meneliti lebih lanjut dengan judul penelitian yaitu "Motif Perilaku Bibliocrime di UPT Perpustakaan UIN

\section{Raden Fatah Palembang".}

Berdasarkan latar belakang yang telah dipaparkan, peneliti merumuskan permasalahan yaitu sebagai berikut : 1) Bagaimana perilaku bibliocrime di UPT Perpustakaan UIN Raden Fatah Palembang?; Apa saja motif yang melatarbelakangi pemustaka untuk melakukan bibliocrime di UPT Perpustakaan UIN Raden Fatah Palembang?; 3) Bagaimana dampak kerugian yang ditimbulkan oleh perilaku bibliocrime di UPT Perpustakaan UIN Raden Fatah Palembang?; 4) Bagaimana upaya pencegahan yang telah dilakukan oleh UPT Perpustakaan UIN Raden Fatah Palembang dalam meminimalisir perilaku bibliocrime?

\section{B. TINJAUAN PUSTAKA}

Pada tinjauan pustaka ada dua cakupan yang diuraikan, yakni meliputi uraian riset-riset ilmiah yang mempunyai relevansi dengan pokok permasalahan perilaku bibliocrime, dan teori-teori yang digunakan sebagai landasan dalam penelitian ini. Beberapa penelitian terdahulu yang berhubungan dengan perilaku Bibliocrime, pertama, Penelitian yang dilakukan oleh Amri Hariri (2015) yang bertujuan untuk meneliti bagaimana perilaku bibliocrime di Perpustakaan UGM. Penelitian ini merupakan jenis penelitian deskriptif. Metode pengumpulan data menggunakan teknik observasi, wawancara dan dokumentasi. Analisis data (1) pengumpulan data, (2) reduksi data, (3) penyajian data, dan (4) penarikan kesimpulan (Hariri, 2015). Penelitian Amri Hariri memfokuskan penelitian pada bentuk bibliocrime dan pemahaman pustakawan tentang bibliocrime, dan penelitian tersebut tidak membahas mengenai motif perilaku bibliocrime.

Kedua, Isnawan Latif (2016) mengungkapkan tujuan penelitian adalah untuk : (1) Mengetahui bibilocrime di Perpustakaan IST Akprind Yogyakarta; (2) Mengetahui kualitas pelayanan di Perpustakaan IST Akprind Yogyakarta; (3) Mengetahui pengaruh bibliocrime terhadap kualitas pelayanan di Perpustakaan IST Akprind Yogyakarta. Jenis penelitian adalah penelitian deskriptif kuantitatif. Populasi dalam penelitian ini yaitu seluruh anggota Perpustakaan IST Akprind Yogyakarta sampai 2016 dengan jumlah 3491 pemustaka dengan sampel sebanyak 
97 responden (Latif, 2016). Penelitian tersebut berfokus pada pengaruh bibliocrime terhadap layanan, sedangkan penelitian saat ini berfokus pada motif yang melatarbelakangi terjadinya bibliocrime.

Ketiga, Listiyani (2015) dalam skripsinya membahas mengenai berbagai tindakan penyalahgunaan koleksi perpustakaan yang meliputi : pencurian, mutilasi, peminjaman tidak sah, dan vandalisme di Perpustakaan Umum Yayasan LIA Pramuka. Faktor-faktor pendorong penyalahgunaan koleksi, upaya pencegahan dan penanganan yang dilakukan oleh pihak perpustakaan juga dibahas berikut kerugian yang diderita oleh perpustakaan akibat terjadinya tindakan penyalahgunaan ini. Penelitian ini adalah penelitian kualitatif dengan metode deskriptif. (Listiyani, 2010). Dalam penelitian tersebut memfokuskan pada bentuk bibliocrime, faktorfaktor terjadinya perilaku bibliocrime dan upaya pencegahan, sedangkan penelitian saat ini selain meneliti hal tersebut juga meneliti mengenai motif yang melatarbelakangi perilaku bibliocrime.

Keempat, dalam jurnal yang ditulis oleh Damayanti dkk. (2015), membahas mengenai upaya perpustakaan kementerian pendidikan dan kebudayaan Jakarta dalam menurunkan angka tindakan penyalahgunaan koleksi yang meliputi: pencurian, vandalisme, mutilasi dan peminjaman tidak sah. Penelitian ini menggunakan metode kualitatif. Data diperoleh melalui observasi, wawancara mendalam dan tidak terstruktur serta didukung dengan triangulasi oleh ahli preservasi koleksi perpustakaan (Damayanti dkk, 2015 :147-154). Penelitian yang dilakukan oleh Damayanti dkk, menjelaskan bentuk tindakan bibliocrime dan upaya yang dilakukan oleh perpustakaan Kemendikbud dalam mencegah bibliocrime, pada penelitian tersebut tidak membahas motif yang melatarbelakangi perilaku bibliocrime.

Kelima, dalam penelitiannya Adrimon Tustiver (2013), membahas tentang faktor penyebab terjadinya unauthhorized borrowing atau peminjaman bahan pustaka yang tidak sah oleh pemustaka di Kantor Arsip, Perpustakaan dan Dokumentasi Kota Padang. Jenis penelitian ini adalah deskriptif kualitatif (Tustiver dan Nelisa, 2013). Peneltian Tustiver dan Nelisa ini hanya memfokuskan pada salah satu bentuk bibliocrime yaitu faktor peminjaman tidak sah, sedangkan penelitian 
saat ini juga membahas mengenai bentuk bibliocrime lainnya dan motif yang melatarbelakangi perilaku bibliocrime.

Namun dari beberapa penelitian terdahulu yang peneliti cantumkan terdapat beberapa persamaan penelitian yaitu sama-sama meneliti tentang bibliocrime atau penyalahgunaan koleksi, dampak dari perilaku bibliocrime bagi perpustakaan, dan upaya pencegahan terhadap bibliocrime

Sedangkan untuk teori, ada beberapa landasan teori tentang motif, perilaku dan bibliocrime yang menjadi dasar atau landasan dalam penelitian ini. Pertama, teori Motif. Pada penelitian ini, teori motif yang digunakan adalah Motif aktualisasi diri (self-actualization) dari Maslow. Motif aktualisasi diri merupakan motif yang berkaitan dengan kebutuhan atau dorongan untuk mengaktualisasikan potensi yang ada pada diri individu. Kebutuhan aktualisasi diri ini adalah kebutuhan yang tertinggi dalam hirarki kebutuhan yang dikemukakan oleh Maslow. Jika diurutkan kebutuhan tersebut, maka kebutuhan yang paling tinggi adalah aktualisasi diri, kebutuhan akan penghargaan seperti kebutuhan akan prestige (gengsi atau wibawa), sukses, dan harga diri; kebutuhan memiliki dan kasih sayang, seperti misalnya kebutuhan akan afeksi, afiliasi, identifikasi, kebutuhan rasa aman, seperti tenteram, teratur, kepastian; kebutuhan fisiologis merupakan kebutuhan yang pertama dan utama, sedangkan kebutuhan aktualisasi diri merupakan kebutuhan yang paling tinggi.

Kedua, Teori Prilaku. Pada penelitian memfokuskan pada satu teori yaitu teori atribusi, untuk mengetahui penyebab seseorang berperilaku.Teori atribusi dikemukakan oleh Fritz Heider dan teori ini menyangkut lapangan psikologi sosial. Teori atribusi merupakan teori yang menjelaskan tentang perilaku seseorang. Teori ini ingin menjelaskan sebab-sebab perilaku orang, apakah perilaku itu disebabkan oleh disposisi internal ataukah keadaan eksternal. Teori atribusi menjelaskan bagaimana orang menyimpulkan penyebab tingkah laku yang dilakukan diri sendiri atau orang lain. Teori ini menjelaskan proses yang terjadi dalam diri kita sehingga kita memahami tingkah laku kita sendiri dan orang lain.

Fritz Heider, mengemukakan beberapa penyebab yang mendorong orang memiliki tingkah laku tertentu yaitu : 1) Penyebab situasional - orang dipengaruhi 
oleh lingkungannya; 2) Adanya pengaruh personal - ingin memengaruhi sesuatu secara pribadi; 3) Memiliki kemampuan - mampu melakukan sesuatu; 4) Adanya usaha -mencoba melakukan sesuatu; 5) Memiliki keinginan - ingin melakukan sesuatu; 6) Adanya perasaan - perasaan menyukai sesuatu; 7) Rasa memiliki - ingin memiliki sesuatu; 8) Kewajiban - perasaan harus melakukan sesuatu; 9) Diperbolekan melakukan sesuatu (Morissan, 2015: 75).

Ketiga, Teori Bibliocrime. Dalam dunia perpustakaan koleksi adalah salah satu aset yang berharga dari tindakan yang akan merugikan seperti bibliocrime. Bibliocrime adalah suatu bentuk tindakan kejahatan terhadap koleksi. Dalam penelitian ini bibliocrime dipahami sebagai bentuk penyalahgunaan terhadap koleksi yang ada di perpustakaan.

Ada beberapa faktor yang menyebabkan terjadinya perilaku bibliocrime yaitu: a) Kemudahan akses; b) Koleksi yang diminati; c) Usia Pemustaka. Bibliocrime di perpustakaan rata-rata dilakukan oleh anak-anak dan remaja; d) Jam buka operasional; e) Fasilitas fotokopi; f) Kurangnya pengamanan; g) Tidak adanya pelatihan staf perpustakaan dalam pencegahan bibliocrime; h) Desain gedung dan ruang perpustakaan; i) Peraturan perpustakaan. peraturan perpustakaan yang pada umumnya hanya memberikan sanksi ringan terhadap pelaku kejahatan di perpustakaan (Listiyani, 2015 : 29). Hal ini membuat kejahatan di perpustakaan seringkali terjadi berulang-ulang.

Sementara mengenai bentuk-bentuk Bibliocrime, menurut Obiagwu perilaku bibliocrime digolongkan menjadi empat, yaitu; Pertama, pencurian (theft), Pencurian merupakan bentuk kejahatan yang kerap terjadi di sebuah perpustakaan. Pencurian di perpustakaan dapat digolongkan menjadi dua jenis yaitu : Pencurian sistematis, jenis pencurian yang direncanakan, dimana seseorang datang ke perpustakaan dengan maksud untuk mencuri. Dan Pencurian tidak sistematis, pencurian yang tidak direncanakan, dimana seseorang mencuri buku di perpustakaan dengan prosedur yang berlaku kemudian ia bermaksud akan mengembalikan buku tersebut sesuai dengan jangka waktu yang telah ditetapkan tetapi tidak pernah mengembalikan buku tersebut ke perpustakaan (Anggi S., 2017: 12). 
Kedua; perobekan (mutilation), Mutilasi adalah tindakan pemotongan, penghilangan bagian dari buku, dari artikel, ilustrasi dari jurnal, ensiklopedi, dan lain-lain tanpa atau dengan menggunakan alat. Tindakan perobekan dapat mengakibatkan kualitas dari suatu buku menjadi berkurang. Dikarenakan buku merupakan salah satu sumber informasi, jika ada bagian yang hilang ataupun dirobek maka kandungan informasi dari buku tersebut menjadi tidak lengkap lagi. Akibatnya, transfer informasi pun menjadi terhalang.

Tindakan mutilasi dapat berbentuk berbagai macam, antara lain adalah : Perobekan halaman cover/sampul bahan pustaka, perobekan satu halaman bahan pustaka, dan perobekan beberapa halaman dari suatu bahan pustaka (Listiyani, : 17). Orang yang melakukan perobekan disebut bibliocast. Seperti yang diungkapkan oleh Raabe bahwa jika seseorang meminjam buku dari perpustakaan kemudian membaca/melihat halaman menarik, kemudian tak tahan untuk memilikinya sehingga merobek atau mengoyaknya, maka dia sudah menjadi bibliocast atau penghancur buku (Hariri, : 20).

Beberapa alasan yang mendorong seseorang melakukan tindakan mutilasi adalah : 1) Waktu peminjaman terbatas dan peminjam masih membutuhkan buku itu sehingga ia melakukan perobekan; 2) Masalah fotokopi; 3) Koleksi skripsi dan tandon yang tidak boleh dipinjam; 4) Adanya akses tertutup; 5) Ketamakan seseorang, dan 6) Tidak adanya rasa tanggung jawab pengguna perpustakaan dalam memanfaatkan koleksi (Listiyani, 2015 : 16).

Ketiga, peminjaman tidak sah (unauthorized borrowing). Bentuk peminjaman tidak sah adalah mengambil koleksi dari rak tanpa melalui prosedur peminjaman yang sah dengan niat dikembalikan setelah selesai digunakan. Selain itu, menyembunyikan buku yang berada di dalam perpustakaan untuk digunakan secara ekslusif demi kepentingan pribadi, dan meminjam bahan pustaka sampai melebihi batas waktu yang peminjaman (Obiagwu, 1992 : 292). Dan menurut Sinaga, peminjaman tidak sah sama dengan peminjaman yang tidak prosedural. Model kejahatan ini bisa terjadi karena adanya hubungan proksimiti (hubungan kedekatan) atau hubungan kolegial antara pemustaka dengan staf perpustakaan atau 
kepala perpustakaan yang bersangkutan, sehingga peminjaman bisa dilakukan tanpa melalui aturan-aturan yang baku di sebuah perpustakaan (Sinaga, : 14).

Keempat vandalisme (vandalism). Menurut Syaikhu vandalisme adalah tindakan perusakan bahan pustaka dengan menulisi, mencoret-coret, memberi tanda khusus atau membasahi buku. Tindakan ini dapat mengurangi kenyamanan (Syaikhu HS, 2011: 36). Sementara, menurut Kharisman, vandalisme di perpustakaan merupakan suatu perusakan barang-barang milik umum atau milik orang lain dengan cara penambahan, penghapusan, dan pengubahan tulisan yang secara sengaja dilakukan. Vandalisme dikatakan sebagai perusakan dan merupakan tindakan kejahatan karena dilakukan dengan tanpa izin dan tidak sesuai dengan prosedur yang benar terhadap benda-benda milik orang lain atau umum (publik) sehingga istilah vandalisme di perpustakaan merupakan salah satu bentuk kejahatan (Fatmawati, 2007).

Menurut Coben, Miller dan Stokols, mereka menyebutkan bahwa dalam rangka menganalisis bentuk-bentuk dan penyebab vandalisme, mereka membagi penyebab vandalisme menjadi 5 jenis dilihat dari kondisi psikologis seseorang, yaitu : 1) Ekspresi dari suatu protes sosial;2) Dendam; 3) Kebencian; 4) Aktualisasi diri; dan 5) Manifestasi perilaku kewilayahan (Listiyani, 2015 : 25 dan 29). Jadi, vandalisme adalah bentuk bibliocrime berupa perusakan bahan pustaka dengan cara menulisi, mencoret-coret, memberi tanda khusus, membasahi, mengotori, membakar dan lain lain. Penyebab vandalisme bisa bermacam-macam seperti dikarenakan adanya kebencian, ekspresi dari suatu proses sosial, dendam, aktualisasi diri, kekuasaan dan bentuk kemarahan dari perilaku individu itu sendiri.

Adanya perilaku bibliocrime tentu mempunyai dampak kerugian bagi perpustakaan. Terdapat dua jenis kerugian yang dialami yakni kerugian sosial dan kerugian finansial (Damayanti dkk, 2015 : 151). Kerugian sosial, kerugian sosial dirasakan apabila banyak pengguna yang kesulitan memperoleh koleksi yang diinginkan karena koleksi tersebut hilang atau rusak, dan mengakibatkan tingkat penggunaan koleksi perpustakaan semakin menurun. Kerugian finansial, Perpustakaan akan mengalami kerugian finansial yang besar apabila pemustaka banyak melakukan tindakan bibliocrime. Hal ini mengakibatkan dana yang diterima 
perpustakaan harus lebih banyak direlokasi untuk perbaikan atau pembelian buku yang hilang. Apabila tindakan bibliocrime ini tidak dicegah maka perpustakaan tersebut akan menjadi sebuah gedung informasi tanpa bermanfaat bagi pemustaka.

Dalam upaya pencegahan bibliocrime ada 3 aspek harus diperhatikan untuk mengurangi tindakan bibliocrime yaitu : (1) Keamanan fisik (physical security) perpustakaan, yang mencakup arsitektur, staf keamanan, dan perangkat keras, seperti perlindungan pada pintu dan jendela; (2) Sistem keamanan elektronik meliputi tattle tape, security gate, CCTV dan RFID. Penggunaan teknologi keamanan seperti tattle tape, security gate, radio frecuency identification (RFID), dan closed circuit television (CCTV); dan (3) Sistem keamanan prosedural, yang meliputi layanan fotokopi, penambahan jumlah eksemplar, patroli yang dilakukan oleh staf dan pendidikan pemakai (user education) (Damayanti dkk, : 153).

\section{METODE PENELITIAN}

Jenis penelitian deskriptif kualitatif, dan pendekatan ilmu yang digunakan adalah bidang keilmuan psikologi. Sumber data, pada penelitian ini terdiri dari dua, 1) Data Primer, pemustaka UPT perpustakaan UIN Raden Fatah Palembang yang diambil dengan teknik purposive sampling yaitu teknik pengambilan sampel dengan pertimbangan tertentu. Adapun kriteri pemustaka yang menjadi informan dalam penelitian ini adalah pertama, bersedia untuk menjadi informan dan keduan pemustaka yang pernah melakukan tindakan bibliocrime. Jumlah informan adalah 13 orang. 2) Pustakawan diantaranya Kepala UPT Perpustakaan UIN Raden Fatah Palembang, Koordinator Sirkulasi dan Multimedia, serta Koordinator Pengadaan dan Pengolahan Bahan Pustaka. Sementara data Sekunder yang dikumpulkan dalam penelitian ini berupa pedoman perpustakaan, data sirkulasi, data koleksi rusak, dan hasil riset/penelitian yang berkenaan dengan judul penelitian.

Teknik pengumpulan data menggunakan 3 metode pengumpulan data yaitu : 1) Observasi, beberapa informasi yang diperoleh dari hasil observasi adalah sebagai berikut : susunan koleksi di rak, Kondisi koleksi, Perilaku pemustaka saat mencari koleksi di rak dan Fisik perpustakaan. 2) Wawancara Mendalam, 3) 
Dokumentasi, dokumen dalam penelitian ini berupa gambar/foto koleksi yang telah mengalami tindakan bibliocrime.

Analisis data, dalam melakukan proses analisis data dimulai dengan menelaah seluruh data yang tersedia dari berbagai sumber. Setelah data dalam penelitian ini dikumpulkan melalui observasi, wawancara dengan informan dan dokumen, maka data tersebut akan dianalisis dengan menggunakan teknik analisis data sebagai berikut : Reduksi Data, Penyajian Data dan Penarikan Kesimpulan (Usman dan Purnomo, 2004 : 86). 1) Reduksi Data, 2) Pada penyajian data, dan 3) Penarikan Kesimpulan.

\section{HASIL DAN PEMBAHASAN}

Pada bagian hasil temuan penelitian, dijelaskan temuan mengenai motif yang menyebabkan pemustaka melakukan bibliocrime, dampak perilaku bibliocrime dan upaya pencegahan.

\section{Pemahaman Informan tentang Bibliocrime}

Untuk mengetahui pemahaman informan tentang bibliocrime, peneliti melakukan wawancara kepada 3 orang yang setiap harinya bergelut dalam bidang perpustakaan, yaitu kepala perpustakaan, staf perpustakaan bagian sirkulasi dan staf perpustakaan bagian referensi. Berdasarkan hasil wawancara dengan kepala perpustakaan UPT Perpustakaan UIN Raden Fatah Palembang, staf bagian sirkulasi, dan staf bagian referensi dapat disimpulkan bahwa ketiga informan memahami tentang bibliocrime, mereka memahami bibliocrime sebagai kejahatan terhadap koleksi yang ada di perpustakaan, meskipun belum mengetahui secara detail mengenai bentuk-bentuk bibliocrime. Pernyataan informan tentang pemahaman terhadap bibliocrime sudah sesuai dengan pernyataan dari Obiagwu yang mendefinisikan bibliocrime sebagai bentuk kejahatan terhadap koleksi atau penyalahgunaan koleksi yang ada di perpustakaan.

\section{Perilaku Bibliocrime di UPT Perpustakaan UIN Raden Fatah Palembang}

Bibliocrime merupakan tindakan yang tidak menyenangkan, karena tindakan tersebut dapat merusak ketentraman perpustakaan dan merugikan berbagai pihak, khususnya perpustakaan. Bibliocrime sendiri merupakan istilah yang 
digunakan untuk menggambarkan perilaku penyalahgunaan koleksi perpustakaan, di mana pemustaka tidak bertanggung jawab dalam memanfaatkan layanan perpustakaan yang dilakukan secara tidak sesuai dan akhirnya menyebabkan terjadinya penyalahgunaan dalam pemanfaatan koleksi.

Sebagai perpustakaan perguruan tinggi, UPT Perpustakaan UIN Raden Fatah Palembang sangat berperan penting dalam memberikan informasi dan selalu dituntut untuk memenuhi kebutuhan informasi para civitas akademikanya. UPT Perpustakaan UIN Raden Fatah Palembang tentu berusaha untuk memberikan yang terbaik bagi pemustakanya. Namun terkadang ada saja pemustaka lain yang berperilaku tidak seharusnya di dalam perpustakaan, dengan melanggar aturanaturan yang telah ditetapkan oleh perpustakaan tersebut, sehingga berdampak buruk bagi perpustakaan. Hal tersebut ditunjukkan dengan banyaknya koleksi yang rusak dan hilang.

Berdasarkan dari pernyataan yang telah dikemukakan oleh informan kepala perpustakaan dan staf perpustakaan, dapat disimpulkan bahwa UPT Perpustakaan UIN Raden Fatah Palembang pernah terjadi perilaku bibliocrime. Bibliocrime yang sering terjadi adalah perobekan yang diketahui dengan banyaknya koleksi yang rusak akibat dirobek dan peminjaman tidak sah dengan seringnya terlambat mengembalikan buku dan meminjam kartu milik orang lain. Pencurian dan vandalisme juga pernah terjadi di perpustakaan tersebut. Namun, dari segi banyaknya koleksi yang divandalisme, perpustakaan belum menghitung secara pasti berapa jumlah koleksi yang divandalisme, karena perpustakaan belum melakukan stock opname.

Selain mendapatkan keterangan dari pihak perpustakaan, peneliti juga menemukan beberapa informan yang mengaku pernah melakukan bibliocrime di perpustakaan, dan bersedia untuk diwawancarai. Berikut bentuk-bentuk bibliocrime yang pernah terjadi di UPT Perpustakaan UIN Raden Fatah Palembang, berdasarkan pernyataan dari informan (pemustaka), adalah: Pertama, Pencurian. Berdasarkan pernyataan informan di atas dapat dipahami bahwa pertama informan pernah tidak mengembalikan buku perpustakaan, bentuk pencurian tersebut merupakan bentuk pencurian sistematis. Kedua, informan membawa buku keluar 
perpustakaan tanpa melakukan peminjaman, bentuk pencurian tersebut merupakan bentuk pencurian tidak sistematis. Hal ini sesuai dengan yang telah dikemukakan oleh Bean dalam Listiyani bahwa pencurian di perpustakaan dapat digolongkan menjadi dua jenis yaitu pencurian sistematis dan pencurian tidak sistematis (Listiyani, 2015 : 14). Jadi, di UPT Perpustakaan pernah terjadi pencurian koleksi baik itu pencurian yang dilakukan sistematis atau pencurian tidak sistematis.

Kedua, hasil mengenai tindakan perobekan yang didapatkan, antara lain adalah : Perobekan halaman cover/sampul bahan pustaka, perobekan satu halaman bahan pustaka, perobekan beberapa halaman dari suatu bahan pustaka (Listiyani, 2015 : 17). Beberapa informan mengaku pernah melakukan perobekan di perpustakaan. Dengan demikian dapat dipahami bahwa informan pernah melakukan perobekan koleksi, baik itu satu lembar maupun beberapa lembar. Koleksi yang dirobek adalah koleksi skripsi dan buku.

Ketiga, Peminjaman Tidak Sah. Menurut Obiagwu, bentuk peminjaman tidak sah adalah mengambil koleksi dari rak untuk digunakan dirumah tanpa melalui prosedur peminjaman yang sah dengan niat dikembalikan setelah selesai digunakan. Selain itu, menyembunyikan buku yang berada di dalam perpustakaan untuk digunakan secara ekslusif demi kepentingan pribadi, dan meminjam bahan pustaka sampai melebihi batas waktu yang peminjaman (Obiagwu, : 292). Hasil penelitian didapatkan bahwa Peminjaman tidak sah pernah dilakukan oleh beberapa informan di UPT Perpustakaan UIN Raden Fatah Palembang. Seperti meminjam koleksi memakai kartu orang lain, pelanggaran batas waktu peminjaman, dan menyembunyikan buku di perpustakaan untuk kepentingan pribadi.

Keempat, Vandalisme. Vandalisme atau mencoret-coret buku dilakukan seperti untuk memberi tanda yang penting baik pada satu kata, kalimat atau paragraf, mencoret-coret halaman buku yang kosong (Syaikhu HS, : 36). Berdasarkan hasil wawancara yang telah dilakukan peneliti di atas, beberapa informan mengaku pernah melakukan tindakan vandalisme di UPT Perpustakaan UIN Raden Fatah palembang, diantaranya seperti mencoret-coret buku, melipat buku, menggarisbawahi kata, kalimat atau paragraf. 
Dari beberapa pernyataan yang telah dijelaskan diatas dapat ditarik kesimpulan bahwa perilaku bibliocrime yang pernah terjadi di UPT Perpustakaan UIN Raden Fatah Palembang adalah pencurian, perobekan, peminjaman tidak sah dan vandalisme. Hal tersebut sesuai dengan pernyataan dari Obiagwu yang menyebutkan bahwa perilaku bibliocrime terdiri dari 4 yaitu pencurian, perobekan/mutilasi, peminjaman tidak sah dan vandalisme. Keempat bentuk bibliocrime tersebut sudah pernah terjadi dan bahkan sering dilakukan oleh pemustaka.

\section{Motif yang Melatarbelakangi Perilaku Bibliocrime}

Setiap perilaku yang ditimbulkan oleh manusia, tentu mempunyai motif atau alasan yang melatarbelakangi perilaku tersebut. Untuk mengetahui motif dibalik perilaku bibliocrime yang ditimbulkan oleh pemustaka UPT Perpustakaan UIN Raden Fatah Palembang, peneliti telah mewawancarai 13 orang informan dan mempunyai jawaban yang bermacam-macam. Adapun motif yang melatarbelakangi pemustaka melakukan bibliocrime dan cara yang mereka gunakan dalam melakukan bibliocrime adalah sebagai berikut : dikarenakan adanya kebutuhan untuk memenuhi tugas perkuliahan yang sedang mereka jalani dan karena lupa yang membuat mereka sampai akhirnya malas untuk mengembalikan koleksi tersebut. Cara yang mereka gunakan adalah dengan menyembunyikan di dalam pakaiannya yaitu dijilbab dan meminjam koleksi tanpa mengembalikannya lagi ke perpustakaan.

Selain pencurian, perobekan juga pernah dilakukan oleh informan. Semua informan memberikan pernyataan bahwa, dalam melakukan perobekan, mereka tidak menggunakan alat apapun, melainkan hanya menggunakan tangan kosong. Hal tersebut dikarenakan memang beberapa koleksi yang ada di perpustakaan seperti lem penjilidan pada skripsi mudah lepas, sehingga memudahkan informan untuk mengambil ataupun merobek koleksi tersebut. Lokasi informan melakukan perobekan pun berbeda-beda, yaitu pada saat berada di perpustakaan dan pada saat telah meminjam koleksi dan membawanya pulang ke rumah. 
Motif yang melatarbelakangi informan melakukan perobekan adalah untuk bahan referensi skripsi, koleksi yang tidak bisa dipinjamkan, biaya fotokopi yang mahal, dan koleksi yang diminati. Koleksi yang tidak bisa dipinjamkan menjadi alasan pemustaka melakukan perobekan. Hal ini dikarenakan adanya beberapa koleksi yang tidak bisa dipinjam oleh pemustaka. Sehingga mendorong pemustaka melakukan perobekan pada koleksi yang ia butuhkan dalam jangka waktu yang lama. Biaya fotokopi yang mahal juga menjadi alasan pemustaka melakukan perobekan. Koleksi yang diminati oleh pemustaka, adanya ketertarikan pemustaka terhadap suatu koleksi seperti novel juga mendorong pemustaka untuk melakukan perobekan.

Salah satu perilaku bibliocrime yang sering dilakukan oleh pemustaka adalah peminjaman tidak sah. Seperti yang telah diungkapkan oleh beberapa informan dari pemustaka bahwa dalam melakukan peminjaman dengan memakai kartu orang lain, informan biasanya meminjam kartu anggota milik teman dekatnya. Hal ini dikarenakan informan tidak mempunyai kartu anggota, baik itu tidak pernah mendaftar sebagai anggota di perpustakaan maupun kartu anggotanya tertinggal. Sedangkan dalam menyembunyikan buku, informan mengaku menyembunyikan koleksi tersebut pada tempat yang sulit dijangkau dan dilihat oleh pemustaka lainnya, agar jika suatu waktu membutuhkannya kembali, mereka dapat menemukannya dengan mudah tanpa harus mencari di rak.

Motif informan melakukan peminjaman tidak sah dikarenakan sulitnya mencari koleksi di rak, koleksi yang terbatas, kartu anggota yang tertinggal, tidak memiliki kartu anggota, dan kartu anggota hilang. Keinginan pemustaka untuk meminjam dan memanfaatkan koleksi di perpustakaan terkendala karena hal-hal tersebut. Selain itu, pemustaka yang terlambat mengembalikan koleksi di perpustakaan dikarenakan disibukkannya dengan berbagai macam aktivitas dan lupa. Hal itulah yang mendorong pemustaka melakukan peminjaman tidak sah di perpustakaan.

Selanjutnya mengenai vandalisme, informan mempunyai cara mereka masing-masing, dan juga tentu mempunyai motif yang melatarbelakangi informan melakukan vandalisme. Dari beberapa pernyataan informan di atas dapat 
disimpulkan bahwa informan melakukan vandalisme dengan cara mencoret-coret, menggambar, menandai, dan menggarisbawahi point-point, kalimat, istilah yang menurut mereka penting, menggunakan stabilo, pena dan pensil. Informan yang menandai dan menggarisbawahi tulisan pada suatu koleksi dikarenakan ingin menandai point-point, kalimat, dan istilah yang mereka anggap penting.

Informan juga mengaku bahwa ia menggambar sesuatu dengan disertai namanya pada halaman kosong, sehingga memanfaatkan halaman kosong pada buku yang ada di perpustakaan. Hal tersebut dapat dipahami bahwa informan ingin menunjukkan aktualisasi diri mereka dengan cara menggunakan kemampuannya menggambar pada koleksi yang ada di perpustakaan dengan menunjukkan identitas dirinya.

Sementara itu, informan juga mengaku bahwa dalam melakukan vandalisme ia dalam keadaan kesal/marah terhadap seseorang. Hal ini menunjukkan bahwa informan mempunyai masalah pribadi dengan seseorang yang kemudian ia luapkan dengan melakukan vandalisme disalah satu koleksi yang ada di perpustakaan. Dapat dipahami bahwa motif yang melatarbelakangi informan tersebut melakukan vandalisme dikarenakan adanya rasa kebencian atau kekesalan pada seorang. Dari kedua hal tersebut, termasuk ke dalam kategori penyebab vandalisme yang telah dikemukakan oleh Coben, Miller dan Stokols bahwa penyebab seseorang melakukan vandalisme jika dilihat dari kondisi psikologis yaitu dikarenakan adanya kebencian, ekspresi dari protes sosial, dendam, kebencian, aktualisasi diri dan manifestasi perilaku kewilayahan.

Dari ke empat motif jenis bibliocrime yang telah dipaparkan di atas yaitu pencurian, perobekan, peminjaman tidak sah dan vandalisme dapat disimpulkan bahwa motif yang melatarbelakangi informan melakukan bibliocrime di UPT Perpustakaan UIN Raden Fatah Palembang adalah sebagai berikut : Aktualisasi diri, Meluapkan rasa kebencian, Ingin memanfaatkan koleksi secara eksklusif demi kepentingan pribadi, Biaya fotokopi yang mahal, Sulitnya menemukan koleksi, Koleksi yang tidak bisa dipinjamkan, Koleksi yang diminati, Koleksi yang terbatas, Lupa, Malas, dan Adanya kesibukan tertentu. Berdasarkan teori yang telah peneliti 
gunakan, dapat dibuktikan dengan hasil temuan penelitian yang telah didapatkan dari hasil wawancara tentang motif perilaku bibliocrime.

\section{Dampak Perilaku Bibliocrime}

Perilaku bibliocrime merupakan perilaku penyalahgunaan koleksi yang ada di perpustakaan. Perilaku bibliocrime di perpustakaan tentu sangat merugikan, baik bagi perpustakaan itu sendiri maupun bagi pemustaka. Dari beberapa pernyataan yang telah diungkapkan informan, 2 diantaranya menyatakan bahwa kerugian finansial tidak terlalu dirasakan jika dibandingkan dengan kerugian sosial yang diderita oleh pemustaka. Sementara informan lainnya menyatakan bahwa kerugian finansial dirasakan jika ada koleksi yang rusak dan hilang, karena perpustakaan harus mengeluarkan dana untuk memperbaiki buku dan mengadakan kembali buku yang hilang.

Perilaku bibliocrime menimbulkan kerugian sosial, seperti yang dikemukakan oleh Kepala Perpustakaan an staf sirkulasi dan staf referensi bahwa kerugian yang sangat besar. Pemustaka tidak bisa mendapatkan informasi dari buku tersebut secara utuh, akibatnya membuat pemustaka menjadi kecewa dan kesal. Berdasarkan beberapa pernyataan di atas, ketiga informan mempunyai pendapat yang sama yaitu bahwa kerugian sosial lebih besar berdampak kepada pemustaka. Pemustaka merasa kesal dan kecewa ketika kebutuhannya tidak dapat terpenuhi oleh perpustakaan dan memberikan pandangan yang buruk bagi pemustaka terhadap perpustakaan.

\section{Upaya Pencegahan Perilaku Bibliocrime}

Dalam upaya meminimalisir terjadinya perilaku bibliocrime, UPT Perpustakaan UIN Raden Fatah Palembang telah menerapkan beberapa sistem keamanan yaitu sebagai berikut : Sistem Keamanan Fisik, Berdasarkan observasi yang telah dilakukan oleh peneliti, pengelolaan bangunan dilihat dari pintu keluar masuk sudah memiliki posisi yang sesuai, yaitu melewati meja pengembalian koleksi, sehingga staf maupun pustakawan yang ada di meja pengembalian koleksi, dapat melihat secara langsung orang-orang yang memasuki perpustakaan. Namun, 
jika dilihat dari arsitektur bangunan posisi rak yang jauh dari jangkauan penglihatan petugas akibat tertutupi oleh dinding, membuat sulitnya petugas untuk mengawasi secara langsung kegiatan yang dilakukan oleh pemustaka pada saat memanfaatkan koleksi di rak.

Sedangkan Sistem Keamanan Elektronik, berdasarkan pernyataan informan dari pihak perpustakaan bahwa UPT Perpustakaan UIN Raden Fatah Palembang telah menerapkan sistem keamanan elektronik berupa security gate dan CCTV. Setiap koleksi yang ada di UPT Perpustakaan UIN Raden Fatah Palembang telah diselipkan pita magnetik yang kemudian dihubungkan dengan security gate, sehingga ketika koleksi yang dibawa keluar tanpa melalui peminjaman, maka alarm security gate akan berbunyi.

CCTV telah dipasang disetiap sudut, terutama bagian layanan perpustakaan. Namun berdasarkan hasil observasi yang telah peneliti lakukan sebelumnya, sistem keamanan berupa security gate yang ada di perpustakaan tersebut, dirasakan kurang efektif, karena ketika pemustaka melewati security gate tersebut dan memakai atau membawa sesuatu yang berbahan logam kecuali pita logam yang ada di dalam koleksi perpustakaan, security gate tersebut tetap berbunyi. Hal itu sepertinya sudah menjadi hal yang biasa ketika berada di perpustakaan tersebut dan tidak terlalu diperhatikan. Begitu pula dengan CCTV, untuk memantau tindakan bibliocrime seperti perobekan, peminjaman tidak sah dan vandalisme, masih sulit untuk diketahui. CCTV hanya akan dikilas balik ketika ditemukan adanya tindak kejahatan di perpustakaan.

Pada sistem keamanan prosedural, UPT Perpustakaan UIN Raden Fatah Palembang yang telah diterapkan adalah user education/pendidikan pemakai, yang dilaksanakan setiap pada mahasiswa baru UIN Raden Fatah Palembang. Namun, untuk melakukan pengawasan untuk setiap pemustaka yang datang, pustakawan dan staf perpustakaan sulit untuk mengawasi setiap gerak gerik mahasiswa, dikarenakan banyaknya pemustaka yang berkunjung ke perpustakaan. Pustakawan dan staf perpustakaan lebih mengandalkan sistem keamanan elektronik.

Jadi, dapat disimpulkan bahwa sistem keamanan yang telah diterapkan di UPT Perpustakaan UIN Raden Fatah Palembang yaitu pertama sistem keamanan 
elektronik berupa CCTV dan security gate. Kedua, sistem keamanan prosedural yaitu user education. Ketiga, sistem keamanan fisik yaitu sudah memiliki pintu keluar masuk yang sesuai dan aman, meskipun posisi rak dan kegiatan pemustaka tidak bisa dijangkau secara langsung oleh pengawasan petugas perpustakaan. Meskipun beberapa sistem keamanan tersebut masih dirasa kurang efektif, setidaknya bisa meminimalisir kejadian. Hal ini dikarenakan masih sulitnya untuk melacak tindakan bibliocrime tersebut seperti peminjaman tidak sah, pencurian, dan vandalisme. Dan adanya masalah teknis pada sistem keamanan elektronik seperti security gate.

\section{KESIMPULAN}

Berdasarkan hasil temuan dan analisis data, pada penelitian yang berjudul Motif Perilaku Bibliocrime di UPT Perpustakaan UIN Raden Fatah Palembang, dapat disimpulkan bahwa :

1. Perilaku bibliocrime yang pernah terjadi Di UPT Perpustakaan UIN Raden Fatah Palembang adalah perobekan dan vandalisme. Sedangkan untuk jenis bibliocrime yang sering terjadi adalah peminjaman tidak sah dan perobekan. Adapun motif yang melatarbelakangi perilaku bibliocrime adalah sebagai berikut : a) Pencurian, motifnya karena adanya kebutuhan untuk memenuhi tugas perkuliahan, tugas akhir, lupa dan malas; b) Perobekan, motifnya adalah karena koleksi yang tidak bisa dipinjamkan, biaya fotokopi yang mahal, koleksi yang diminati, dan untuk bahan referensi; c) Peminjaman tidak sah, motifnya dikarenakan ingin meminjam koleksi di perpustakaan untuk memenuhi kebutuhan tugas perkuliahan; d) Vandalisme, motif yang melatarbelakangi pemustaka melakukan vandalisme adalah untuk menunjukkan aktualisasi diri dan meluapkan rasa kebencian.

2. Dampak Kerugian Dari Perilaku Bibliocrime, yakni: a) Kerugian Finansial. b) Kerugian Sosial.

3. Upaya pencegahan yang telah dilakukan oleh UPT Perpustakaan UIN Raden Fatah Palembang: pertama, Sistem keamanan elektronik menerapkan CCTV dan 
security gate. Namun, sistem tersebut masih terdapat beberapa kekurangan yaitu adanya kesalahan teknis pada security gate yang belum berfungsi secara efektif. CCTV yang tidak dapat menjangkau posisi maupun sudut ruangan tertentu sehingga kegiatan pemustaka pada saat memanfaatkan koleksi disudut tersebut tidak dapat dijangkau oleh CCTV; kedua, Sistem keamanan prosedural yang telah diterapkan adalah pendidikan pemakai pada setiap mahasiswa baru; ketiga Sistem keamanan fisik, dilihat dari arsitektur bangunan, masih terdapat beberapa sudut ruangan yang sulit dijangkau oleh petugas perpustakaan dalam mengawasi pemustaka.

Saran yang peneliti, hendaknya perpustakaan dapat menyediakan layanan fotokopi, menyediakan koleksi yang sesuai dengan kebutuhan pemustaka, dan memberikan sanksi yang tegas bagi setiap pemustaka yang melakukan perilaku bibliocrime. Bagi perpustakaan hendaknya meningkatkan keamanan dan pengawasan terhadap pemustaka dalam memanfaatkan koleksi, baik dari segi sistem keamanan terutama pada sistem keamanan elektronik yaitu security gate dan CCTV maupun petugas perpustakaan. Bagi pemustaka hendaknya dapat mentaati peraturan yang telah ditetapkan perpustakaan, demi kepentingan bersama. Dan bagi peneliti selanjutnya, diharapkan dapat menjadi bahan referensi maupun sumber data untuk melakukan penelitian selanjutnya dengan lebih memperluas kajian mengenai bibliocrime.

\section{DAFTAR PUSTAKA}

Ajala, Isaac Olugbenga dan Adeolu, Samuel. Library \& Archival Security (Theft and Mutilation of Library Materials in Nigerian Academic Libraries. (Nigeria: 2008). Diakses pada 29 Desember 2019, alamat: http://link.springer.com/chapter/10.1007/978-1-4899-0176-7_11

Damayanti dkk, Upaya Pencegahan Penyalahgunaan Koleksi Perpustakaan Kemendikbud, Jurnal Kajian Informasi dan Perpustakaan, Vol. 3, No. 2 (Desember 2015). Diakses pada 15-06-2018 dari : http://jurnal.unpad.ac.id/jkip/article/download/9977

Fatmawati, Endang. Vandalisme di Perpustakaan, Media Informasi, Vol. 16, No. 1-9, h. 2 (2007). Diakses pada 22 Desember 2019, alamat: http://lib.ui.ac.id/ 
Hariri, Amri. Perilaku Bibliocrime Di perpustakaan Universitas Gadjah Mada, Skripsi, (Yogyakarta : Fakultas Adab dan Ilmu Budaya, Universitas Islam Negeri Sunan Kalijaga, 2015) Diakses pada 05-11-2017 dari : http://digilib.uinsuka.ac.id/19306

Listiyani, Penyalahgunaan Koleksi Perpustakaan : Studi Kasus Di Perpustakaan Umum Yayasan Lia Pramuka, Skripsi, (Depok : Fakultas Ilmu Pengetahuan Budaya, Program Studi Ilmu Perpustakaan, 2010) Diakses pada 26-072018, alamat : http://lib.ui.ac.id/

Morissan, Corry Andy Wardhani, Teori Komunikasi Individu Hingga Masa Kini, (Jakarta: Prenada Media, 2015)

Nur Rahmawati, Guwido. Perilaku Vandalisme Pemustaka di Pusat Perpustakaan Universitas Islam Negeri (UIN) Syarif Hidayatullah Jakarta, skripsi, (Jakarta : Fakultas Adab dan Humaniora, Universitas Islam Negeri Syarif Hidayatullah, 2014) Diakses pada 04-08-2018 dari http://repository.uinjkt.ac.id/dspace/bitsream/123456789/29370/3/Guwido $\% 25$ 0Nur\%252 Rahmawati\%2520-\%2520FAH.pdf

Obiagwu, Marcell. Library Abuse in Academic Institutions : a comparative study, International Information \& Library Review, Vol. 24 Issues 4, 1992. Diakses pada 02-08-2018 pada http://www.researchgate.net/publication/267825089_KEAMANAN_KOL EKSI_PERPUSTAKAAN\&ved=2ahUKEwjahd3cjoreAhWKKo8KHSiR1I QFjAAegQIBxAB\&usg=AOvVaw0iNFT1150Rp6U3Hocdcrk

Sinaga, Dian. Kejahatan Terhadap Buku dan Perpustakaan”. Visi Pustaka Vol. 6 (Juli 2004). Diakses pada http://scholar.google.com/citation?user=4N2GN2gAAAAJ\&hl-420

Syaikhu HS, Akhmad. Keamanan Koleksi Perpustakaan. Jurnal Perpustakaan dan Pertanian 20, No. 1 (7 Maret 2011), h. 36. Diakses pada 05 Januari 2019, alamat:http://duniaperpustakaan.com/file/keamanan\%20Koleksi\%20perpu stakaan.pdf

Tustiver, Adrimon dan Nelisa, Malta. Faktor Peminjaman Tidak Sah (Unauthorized Borrowing) Bahan Pustaka Oleh Pemustaka Di Kantor Arsip Perpustakaan dan Dokumentasi Kota Padang : Jurnal Ilmu Informasi Perpustakaan dan Kearsipan, Vol.2 No. 1, September 2013. diakses pada 12 agustus 2018 dari http://download.portalgaruda.org/article.php\%3farticle\%3d101340\%26val \%3d1515\&ved=2ahukewia7ubtoreahump48khccfcy8qfjaaegqibhab\&usg= aovvaw3utr83qx9 1-ptpjih9e4q

Undang-undang Nomor 43 Tahun 2007 Tentang Perpustakaan. (Jakarta : Indonesia, 2007), pasal 6 ayat 1. h. 5

Usman, Husaini dan Akbar, Purnomo Setiady. Metodologi Penelitian Sosial (Jakarta: PT. Bumi Aksara, 2004) 